УДК

94(100)"1939/1945":316.752(497.11)

340.134:343.294(497.11)"200/201"

Оригинални научни рад

Примљен: 12. 7.2017.

Прихваћен: 22. 12. 2017.

Jelena ĐUREINOVIĆ

Justus Liebig University

Giessen, Germany

Jelena.Dureinovic@gcsc.uni-giessen.de

\title{
Reinterpretation of 7 July: From the Day When the First Insurgent Rifle Fired to the Day of the Outbreak of the Civil War*
}

\begin{abstract}
The article examines the history of memory of 7 July 1941 in the context of the politics of memory on the Second World War in Serbia. Although a rather small-scale event, what happened in Bela Crkva on 7 July has been deemed significant in both socialist Yugoslavia and post-Yugoslav Serbia. However, its interpretation has changed and has always reflected the hegemonic historical narratives about the Second World War and their transformations. The meanings and values ascribed to the event of 7 July and its main actors are in the focus of the paper that takes the diachronic approach to memory with the emphasis on the post-Yugoslav period.
\end{abstract}

Key words: memory politics, the Second World War, Yugoslavia, 1941 Uprising, rehabilitation

On 7 July 1941, a group of Partisans arrived in Bela Crkva, a village in western Serbia, to set up a political rally and speak in front of the local people who had assembled because of the annual village fair. After the assembly had ended, two gendarmes, Bogdan Lončar and Milenko Braković, appeared in the village to disperse the gathering. The Partisans were warned, but they returned and confronted the gendarmes, and Živorad

* The author would like to thank Ciarán Murray for the invaluable support in the process of completing this manuscript. 
Jovanović shot both of them. The day this happened was established as the Day of the Uprising immediately after the war, 7 July becoming a public holiday in the Socialist Republic of Serbia in 1945. It was celebrated annually throughout Serbia as the beginning of the uprising of the people of Serbia against the occupation. ${ }^{1}$ Živorad Jovanović Španac was posthumously decorated with the Order of the People's Hero in 1945. The holiday was abolished by the National Assembly of Serbia with the adoption of the changes to the Law on Holidays in 2001, but was reintroduced in 2013 as the Day of the Uprising in the Second World War, however not regaining the status of a public holiday from the Yugoslav period. In parallel with that, Bogdan Lončar and Milenko Braković were legally rehabilitated in 2008 as the victims of political and ideological violence and persecution.

The above-mentioned changes in the status of 7 July mirror the dominant (re)interpretation of the shooting of the gendarmes in particular as well as the Second World War and its actors in general. During the Yugoslav period, 7 July symbolized the beginning of the uprising against the occupation and the parallel socialist revolution in Serbia. The Second World War, with the People's Liberation Struggle that resulted in the liberation of the country and the establishment of the socialist state as its focal point, represented the main source of legitimacy for the regime. Thus, the day when "the first insurgent rifle fired" was highly significant for the master commemorative narrative and linked exclusively to the positive values. During the rule of Slobodan Milošević, the state had a rather ambiguous relation to the Second World War, those in power not entirely separating themselves from the so-called 'Partisan Myth' but at the same time instrumentalizing the past for the purposes of consolidation of power and war mobilization. The commemorations of the defeated side of the Second World War came mostly from the political opposition and were not significantly sanctioned by the state after 1990 .

After the fall of Slobodan Milošević in 2000, the official positive interpretation of the People's Liberation War was replaced with the utterly opposite image of the Second World War and its actors rooted in the strong anti-communist political consensus among the political parties that came to power. Within the hegemonic discourses of the victimhood under communism and the related criminalization of the people's liberation movement, the Day of the Uprising had to be abolished. The 7 July

$1 \quad$ While 4 July was a public holiday at the Yugoslav level, each republic had a separate holiday commemorating the beginning of the uprising against the occupation within the given republic. 
became the day when "a Serb fired at Serbs", the legal rehabilitation of Lončar and Braković confirming the interpretation of the two gendarmes as the first victims of the civil war within the Serbian nation.

This paper examines the history of memory of the Day of the Uprising. As summarized above, although a rather small-scale event, what happened in Bela Crkva on 7 July has been deemed significant in both socialist Yugoslavia and post-Yugoslav Serbia since 1945. However, its interpretation has changed and has always reflected the hegemonic historical narratives about the Second World War and their transformations. The meanings and values ascribed to the event of 7 July and its main actors are in the focus of the paper that takes a diachronic perspective to the state-supported memory politics, the master commemorative narratives it revolves around, and their politicality. After a brief theoretical introduction, the paper discusses the celebrations of the Day of the Uprising during the socialist period and then focuses on the main issue of its abolishment and reinterpretation after the overthrow of Slobodan Milošević and the legal rehabilitation of Lončar and Braković.

\section{Studying the History of Memory}

Memory as a political and social issue, like it has manifested itself in the "de-communization" policies in post-socialist countries and transitional justice processes in other parts of the world, significantly contributed to the historians' interest in memory as an object of study over the last 20 years, as remembering and overcoming the past has become central to the way states strive for building new identities. ${ }^{2}$ As Peter Burke explains, historians study memory from two perspectives. First, they examine memory as a historical source in order "to produce a critique of reliability of reminiscence on the lines of the traditional critique of historical documents". More importantly for this paper, historians are concerned, or should be concerned, with memory as a historical phenomenon - with what Burke calls the social history of remembering. Taking into consideration the fact that social memory is selective, similarly to the individual memory, Burke argues that historians need to identify the principles of selection and examine how they differ from place to place or from group to group and how they change over time. As "memories are malleable", historians need to understand how they are shaped and by whom, as well as the

2 Stefan Berger and Bill Niven, Writing the History of Memory, (London: Bloomsbury Academic, 2014), 6. 
limits to this malleability. ${ }^{3}$ What Burke calls the social history of remembering is for Berger and Niven the history of memory, another branch of historiography added to the traditional ones as historians are increasingly turning to analysing the nature, extent, and long-term effects of memory. ${ }^{4}$

Memory politics encompasses all discourses and activities by which a certain interpretation of the past is employed for political purposes - as the public representation of the relevant past in the present. ${ }^{5}$ The concept of the politics of memory represents the way "states, state governments, political parties and other elite groups have sought to encourage views of the past which serve their own ends", usually linked to the acquisition, consolidation, and extension of power. ${ }^{6}$ These images of the past can but do not have to be false. Nevertheless, they are often one-sided and tendentious, generated and adapted to suit the interests of the present. ${ }^{7}$ In other words, in the arena of memory politics driven by presentism, "images of the past commonly legitimate a present social order". ${ }^{8}$ As Wertsch argues, states are naturally not the only entities working on collective memory in the modern world, but they are "unrivaled in the power and resources they have devoted to this effort". ${ }^{9}$ Acknowledging the efforts of different groups in purveying certain accounts of the past, he emphasizes that the modern state outweighs them in resources, authority, and restriction of competing efforts. Because of that, the official state-sanctioned efforts still represent a valuable and natural arena for studying collective remembrance. ${ }^{10}$

National memory is usually structured around anniversaries of historical events and their commemorations that represent "mental historical calendar of the nation" ${ }^{11}$ Each commemorative act or ritual re-

3 Peter Burke, Varieties of Cultural History, (Ithaca: Cornell University Press, 1997), 46.

$4 \quad$ Berger and Niven, Writing the History of Memory, 4.

5 Harald Schmid, "Konstruktion, Bedeutung, Macht. Zum kulturwissenschaftlichen Profil einer Analyse von Geschichtspolitik", Geschichtspolitik und sozialwissenschaftliche Theorie, eds Horst-Alfred Heinrich, Michael Kohlstruck, (Stuttgart: Steiner, 2008), 78.

6 Berger and Niven, Writing the History of Memory, 7.

7 Ibid.

8 Paul Connerton, How Societies Remember, (Cambridge and New York: Cambridge University Press, 1989), 3.

9 James Wertsch, Voices of Collective Remembering, (New York: Cambridge University Press, 2002), 10.

10 Ibid., 68.

11 Stefan Berger and Bill Niven, "Writing the History of National Memory", Writing the History of Memory, eds Stefan Berger, Bill Niven, (London: Bloomsbury Academic, 2014), 146. 
produces a certain commemorative narrative that reconstructs a specific fragment of the past. A set of commemorations together form a master commemorative narrative that the official politics of memory mentioned above revolves around. In her study of the politics of memory and construction of national myths in Israel, Yael Zerubavel develops a theoretical framework of master commemorative narrative which is supposed to structure collective memory. She defines it as "a broader view on history, a basic 'story line' that is culturally constructed and provides the group members with a general notion of their shared past". ${ }^{12}$ As individual acts of commemorations contribute to the formation of a master commemorative narrative, they should be examined within a wider context of the narrative they reproduce. This paper takes this as a starting point for the discussion of 7 July and its actors in the wider context of the hegemonic historical narratives and politics of memory on the Second World War, adding the important diachronic perspective to it.

\section{Memory of the Second World War and State Socialism}

The Second World War and second Yugoslavia were inseparably linked to each other. ${ }^{13}$ The war was the founding event and the main legitimacy source for socialist Yugoslavia, which is why the memory of the war and state socialism are deeply intertwined in the post-Yugoslav space, including contemporary Serbia. The drastic turn in the official politics of memory on the Second World War in Serbia happened after the overthrow of Slobodan Milošević in 2000, when the Yugoslav narrative was replaced by a diametrically opposed interpretation of the war and its prominent actors. As Stojanović explains, after the overthrow of Slobodan Milošević, the actors in power had a key goal to make a clear cut with the communist past, which was supposed to make them the liberators of Serbia from communism, as Milošević was referred to as the last European communist and it suited the strong anti-communist climate in Serbia. The reason why the Second World War has been the central subject of the re-

12 Yael Zerubavel, Recovered Roots: Collective Memory and the Making of Israeli National Tradition, (Chicago: Chicago University Press, 1995), 6.

13 Holm Sundhaussen, "Jugoslawien und seine Nachfolgestaaten. Konstruktion, Dekonstruktion und Neukonstruktion von 'Erinnerungen' und Mythen", Mythen der Nationen. 1945 - Arena der Erinnerungen, Bd. 1, ed. Monicka Flacke, (Berlin: Deutsches Historisches Museum, 2004), 374. 
interpretation is because it is considered as a place of "the mythical birth of the communist regime". ${ }^{14}$

A drastic change in the official memory politics on the Second World War followed the fall of state socialism in Central and Eastern Europe. The rapid delegitimization of former state-sponsored master narratives and subsequent spread of previously suppressed aspects of the national past, as Heike Karge explains, encompassed a new cleansing of the past in which the formerly dominant class approaches to 'resistance' and 'collaboration' were to be replaced with a focus that often reflected revisionist tendencies". ${ }^{15}$ She understands 1989 and a decade afterwards as the turning point when a 'dislocation' of collective memories happened, "by means of exchange of ideologies and collective memories instead of a pluralization of the latter" ${ }^{16}$ Although the dominant discourses have been based on the claims about the process of revisiting the past as objective and necessary for overcoming the hegemonic narratives of state socialism, this reinterpretation of the past has been politically driven and imposed from above. As James Mark argues about the memory of the communist past in Central and Eastern Europe, the initiatives of dealing with the past in postsocialism are not "initiatives fundamentally concerned with the democratic pluralization of memory", but they are moral and political projects based on the idea that "the legacies of communism could be best overcome through a powerful institution forging a unitary interpretation of the past from above."17

In the hegemonic historical discourses of postsocialism, "the entire history of communism was reduced to its totalitarian dimension, which appeared as a collective, transmissible memory". ${ }^{18}$ Talking about postsocialist museums, Apor explains that "the emphasis on instances of terror and violence" is not accidental and also has the purpose to repre-

14 Dubravka Stojanović, "U ogledalu drugih", Novosti iz prošlosti: Znanje, neznanje, upotreba i zloupotreba istorije, prir. Vojin Dimitrijević, (Beograd: Beogradski centar za ljudska prava, 2010), 17.

15 Heike Karge, "Practices and Politics of the Second World War Remembrance: (Trans-) national Perspectives from Eastern and Southeastern Europe", A European Memory? Contested Histories and Politics of Remembrance, eds Malgorzata Pakier, Bo Strath, (New York: Berghahn Books, 2010), 138.

16 Ibid., 137-147.

17 James Mark, The Unfinished Revolution: Making Sense of the Communist Past in Central-Eastern Europe, (London: Yale University Press, 2010), 59.

18 Enzo Traverso, Left-Wing Melancholia. Marxism, History, and Memory, (New York: Columbia University Press, 2017), 2. 
sent the previous regimes as imposed on the nations "by the means that were impossible to resist" and were maintained by force and coercion. ${ }^{19}$ Examining the Yugoslav context, Kirn notices the same tendency of the reduction of the revolutionary dimension of the Partisans and the Yugoslav socialist project to the totalitarian spectre of terror, crimes, and the cult of personality. This is present in various forms and degrees in the post-Yugoslav countries, from "attempts to reconcile the opposing sides in the civil war within the framework of particular nations to a more aggressive and fundamentalist tendency that erases and demonizes anything connected with the name of Yugoslavia". ${ }^{20}$

\section{Mnemonic Hegemony vs. Memory Politics from Below}

It should be noted that there is more to collective memory and politics of memory than a top-down dimension that encompasses the agency of the state and other institutions and groups in power positions. As Kansteiner argues, we should think of collective memory as "the result of three types of historical factors: the intellectual and cultural traditions that frame all our representations of the past, the memory makers who selectively adopt and manipulate these traditions, and the memory consumers who use, ignore, or transform such artifacts according to their own interests." ${ }^{21}$ Similarly and drawing on the Gramscian theory of cultural hegemony, Molden thinks of the politics of history and memory as "determined by the relations of forces between hegemonic master narratives, defiant counter-memories, and silent majorities whose historical experience is rarely articulated in the public". ${ }^{22}$ The theory of mnemonic hegemony goes further than a common bipolar approach to one dominant historical narrative imposed from above and a counter-memory from below that stands in juxtaposition to it and replaces it with a "more open, polyphonic view on mnemonic agency". ${ }^{23}$

19 Péter Apor, "Eurocommunism. Commemorating Communism in Contemporary Eastern Europe", A European Memory? Contested Histories and Politics of Remembrance, eds Malgorzata Pakier, Bo Strath, (New York: Berghahn Books, 2010), 236.

20 Gal Kirn, "Transnationalism in Reverse: From Yugoslav to Post-Yugoslav Memorial Sites", Transnational Memory, eds Chiara de Cesari, Ann Rigney, (Berlin: De Gruyter, 2014), 327-328.

21 Wulf Kansteiner, "Finding Meaning in Memory: A Methodological Critique of Collective Memory Studies", History and Theory 41:2/2002, 180.

22 Berthold Molden, "Resistant Pasts versus Mnemonic Hegemony. On the Power Relations of Collective Memory", Memory Studies 9:3/2016, 125.

23 Ibid., 130. 
The acknowledgment of the polyphony of memory and mnemonic agency in a society takes into account the memories and activities of different groups who might have personal links to a historical event but also political motivations often standing behind mnemonic agency from below. This is the sphere of vernacular culture, as John Bodnar defines it, which represents the way people organize themselves and develop commemorative spaces, forms and practices which reflect how they want to remember historical events. ${ }^{24}$ Thinking about memory in pluralistic terms is what Burke also argues for, emphasizing the need to think about the uses of memories to different social groups who might have different views about what is significant or "worthy of memory". ${ }^{25}$ In the context of contemporary Serbia, different memory communities, to borrow the term from Burke, commemorate the Second World War and Yugoslavia, either by striving for preservation of the Yugoslav traditions and practices of remembrance or rejecting it by commemorating the defeated side of the war and even initiating legal measures against what they perceive as the persisting hegemony of the Yugoslav memory culture, usually in the form of legal rehabilitation processes. Although not the main objective of this paper, the examination of the history of memory of 7 July nevertheless implies the approach that takes the pluralism of mnemonic agents into consideration as well as different memory communities in the Serbian society. While the paper focuses on the reinterpretations of the Day of the Uprising in a historical perspective that revolves predominantly around the hegemonic discourses and official memory politics, it also places emphasis on the agency of the actors from below, particularly in the period after 2000 .

\section{Bela Crkva on 7 July 1941}

The Communist Party of Yugoslavia had been making preparations for the armed uprising from April 1941, including organization, setting up networks, and collecting arms. The attack of Nazi Germany on the Soviet Union on 22 June accelerated the organization of the uprising, especially because it left Yugoslavia with much less German military forces present. The formal decision on the general and organized uprising was made at the party leadership meeting in Belgrade on 4 July and the event

24 John Bodnar, Remaking America: Public Memory, Commemoration, and Patriotism in the Twentieth Century, (Princeton: Princeton University Press, 1992).

Burke, Varieties of Cultural History, 55-56. 
in Bela Crkva three days later marked the official beginning of the Partisan uprising in Serbia. The organizational meeting about the uprising in Rađevina area of western Serbia was also held on 4 July in Bela Crkva. The Spanish Civil War veteran Živorad Jovanović Španac and Miša Pantić spoke at the meeting about the need to organize the armed struggle against the occupation, another outcome of the meeting being the decision to organize a public gathering in Bela Crkva on 7 July, because the people would anyway gather for the traditional Saint John's Day village fair. ${ }^{26}$

On 7 July, the group met just outside of Bela Crkva, while Vladan Bojanić remained in the village spreading the word about a political assembly taking place later that day. As summarized by Španac: "It is Sunday. A lot of folks gathered in Bela Crkva. We will hold the political rally. Gendarmes might come so we must secure ourselves. If they come and start forcing the people away, act as soldiers: disarm them or shoot..." ${ }^{27}$ The group of 15 Partisans that later became the Radjevo Unit of the Valjevo Partisan Detachment, entered Bela Crkva and three of them spoke in front of the gathered locals. The speeches were intended to mobilize the people for the uprising against the occupation authorities and their domestic helpers. Different sources and testimonies claim that the peasants responded positively and were especially taken by the speech of Španac.

After the Partisans had left, the gendarmes Bogdan Lončar and Milenko Braković came from the village nearby because they heard of the gathering that was forbidden according to the occupation laws. As they approached Bela Crkva, they met a local teacher who told them that everything had been already over but they replied, "That is precisely why we are going, we want to show them who we are." ${ }^{28}$ The gendarmes started forcing people to leave, threatening them and asking questions about the Partisans. Finally, they found the village president Sredoje Knežević and, while they were interrogating him, the Partisans came back. According to Vjekoslav Spoja, Bojanić, who had stayed in the village, ran after the Partisans and yelled, "The gendarmes are forcing the people away!" which is why they returned. ${ }^{29}$ As Španac was approaching the gendarmes they yelled at him to stop but he continued walking straight towards them. Lončar and Braković both took out their arms and one of them fired

26 „Kako je planula prva ustanička puška u Srbiji“, Politika 12021, 2. 7.1945.

27 Vjekoslav Spoja, “Bio sam kraj Žikice kad je pucao”, Ustanak naroda Srbije 1941, Vol. 2, (Beograd: Vojno delo, 1964), 673.

28 Testimony of Stanko Popović, 24. 8. 1959.

29 Spoja, "Bio sam kraj Žikice”, 674. 
over Španac's head. Španac responded by quickly taking the gun out of his coat and shooting both of them. ${ }^{30}$ The Partisans approached the shot gendarmes and took their arms, Španac yelling to everyone present that everyone who was a people's enemy would end like that. ${ }^{31}$ The reports of the German area and district occupation authorities to the higher command speak about the generally positive reception of the incident in Bela Crkva among the Serbian population and that peasants were inclined to help the insurgents and hide them from the authorities.

\section{The Day of the Uprising of People of Serbia in Yugoslavia}

The Second World War was the main founding event for the socialist state that emerged victorious from the Second World War in the territory of the pre-war Kingdom of Yugoslavia. Memory of the war served as a legitimacy source but it also had an integrating function for the society, revolving around the discourse about the common struggle of all Yugoslav people against the occupation and the domestic traitors. The size and the authentic nature of the People's Liberation War also acted as a strong emancipating factor. ${ }^{32}$ As Heike Karge summarizes, the Yugoslav official war discourse had three elements: the emphasis on the people's liberation, the parallel dimension of the wartime period as a socialist revolution, and, finally, the merge of the first two elements into a single process resulting in the brotherhood and unity of Yugoslav people. ${ }^{33}$ The dominant war narrative was based on the unquestionable paradigm of interpretation, representing the Communist Party of Yugoslavia as the only force that had been consistent in opposing the occupation and collaborationist forces and as the only option for Yugoslavia. ${ }^{34}$

30 Testimony of Sredoje Knežević, 24. 8. 1959. - All witness testimonies from Bela Crkva and by the Partisans can be summarized as above. However, some of the witnesses imply that another Partisan, perhaps Cvetin Soldatović who was next to Španac, might have also fired and shot one gendarme, but no witness could claim this with certainty. Furthermore, the majority of witness accounts implies that the gendarmes shot first while some of them cannot confirm it because they did not see it.

31 Testimony of Bogoljub Lazić, 24. 8. 1959; Dojčilo Mitrović, Zapadna Srbija 1941, (Beograd: Nolit, 1975), 85.

32 Snježana Koren, Politika povijesti u Jugoslaviji (1945-1960). Komunistička partija Jugoslavije, nastava povijesti, historiografija, (Zagreb: Srednja Evropa, 2012), 509.

33 Heike Karge, Steinerne Erinnerung - versteinerte Erinnerung? Kriegsgedenken in Jugoslawien (1947-1970), (Wiesbaden: Harrassowitz Verlag, 2010), 83.

34 Wolfgang Höpken, "Vergangenheitspolitik im sozialistischen Vielvölkerstaat. Jugoslawien 1944-1991", Umkäpfte Vergangenheit. Geschichtsbilder, Erinnerung und Ver- 
In the first post-war years, the narratives about the alliance of the Yugoslav and Soviet people, the leading position of the Soviet Union in the international communist movement, and the role the Red Army played in the victory against fascism were emphasized on the commemorative and other occasions. After the split with the Soviet Union in 1948, the emphasis shifted more significantly towards the Yugoslav Partisans as the carriers of the revolutionary transformation of the society. ${ }^{35}$ The Association of Veterans of the People's Liberation War (from 1961 the Union of Associations of Veterans of the People's Liberation War) was the main mnemonic agent, responsible for the preservation of the war memory. More than 1300 Orders of the People's Hero were awarded to the fighters and units of the People's Liberation War. Many of these medals were given posthumously, such as in the case of Živorad Jovanović Španac.

As a part of the master commemorative narrative of the People's Liberation War, the commemorations of 7 July mirrored the general characteristics of the Yugoslav memory politics. The dominant interpretation of the assassination of Lončar and Braković by Španac and its significance was as "the day when the first insurgent rifle fired" ${ }^{36} \mathrm{~A}$ rather small-scale event was ascribed large significance, being transformed into a grand narrative of the beginning of the organized uprising in Serbia, where both the political speeches held by the Partisans to invite and mobilize the people for the uprising against the occupation and the act of shooting the two gendarmes were important. The assassination of the two particular gendarmes, Lončar and Braković was merged into the larger master commemorative narrative of the war that transcended the actual events in Bela Crkva. The Day of the Uprising was interpreted through the lens of the entire war, the liberation, and the successful establishment of the socialist state that ensued, and was never referred to without the wider con-

gangenheitspolitik im internationalen Vergleich, ed. Petra Bock and Edgar Wolfrum, (Göttingen: Vandenhoeck \& Ruprecht, 1999), 223.

35 Olga Manojlović Pintar, "(Ne)vidljiva mesta sećanja. Spomenici crvenoarmejcima u Srbiji”, Oslobođenje Beograda 1944, (Beograd: Institut za noviju istoriju, 2010), 547.

36 The phrase "when the first insurgent rifle fired" recurs in Yugoslav newspapers, diverse publications, and speeches of the Yugoslav officials. Živorad Jovanović Španac did not use a rifle, but he shot the gendarmes with the Steier gun which he had had in his coat. Over the last years, the assumption appeared in newspaper articles and popular history books that it came from the speech of Josip Broz Tito at the 1945 commemoration in Bela Crkva. However, the daily newspaper Politika had used this phrase on its cover page the day before the 1945 commemoration. 
text of the general uprising that spread throughout the country and the outcome of the war.

The Day of the Uprising of the People of Serbia on 7 July was declared by the Presidency of the People's Assembly of Serbia in July 1945, when Živorad Jovanović Španac was also decorated by the Order of the People's Hero. Besides the central and largest celebration in Bela Crkva, the Day of the Uprising was commemorated by annual celebrations throughout the whole Republic of Serbia on 7 July. Judging from the newspaper reports, the central celebrations in Bela Crkva gathered between 10 and 20 thousand people. The commemorative activities and celebrations were well represented in media, the newspapers in Serbia dedicating several pages to the commemorations as well as to the stories about 7 July 1941 during the entire week.

The holiday was used as an opportunity for the local communities to reveal new monuments, open museums, and decorate local veterans of the People's Liberation War. The local communities, counties, and regions commemorated the beginning of the uprising in their areas in parallel with the anniversary of the general uprising of Serbia. The anniversary celebrations encompassed a rich cultural program and were massively attended by young people and families, who enjoyed the nature making picnics or camping, as many commemorations were either on mountains or in parks in cities. Moreover, different re-enactment marches were a practice in some parts of Serbia.

The first celebration of the Day of the Uprising in Bela Crkva was held in 1945. It was attended by Josip Broz Tito and the highest Yugoslav, Soviet, and other foreign officials. The event in 1945 was not just a typical war commemoration; it rather resembled a large village fair with food, music, and fireworks. That practice continued during the Yugoslav period. Similar celebrations were organized in Belgrade, at Kosmaj, and Bukulja. For the first celebrated anniversary of the Day of the Uprising in 1945, the houses in Bela Crkva were newly painted. The flags of the Soviet Union and Allies and the portraits of Tito and Stalin were on display around the village, as well as the large slogan "Long live great Stalin, the organizer of the victory against fascism!" ${ }^{37}$ The alliance and brotherhood with the Soviet Union and its people was the notable theme in the speeches of Tito and others, with the particular acclaim for Stalin by the speakers as well as the gathered people in the audience. While the general interpretation of the

37 „Veličanstvene svečanosti u Beloj Crkvi, na Kosmaju i u Beogradu”, Politika 12027, 8. 7. 1945. 
events of 7 July did not change during the entire Yugoslav period, the references to the Red Army and the Soviet Union and praises to Stalin have disappeared after 1948.

Josip Broz Tito attended only the celebration in Bela Crkva in 1945. In the years to come, he congratulated Serbian people on the holiday through newspapers, but he attended the all-Yugoslav celebration of 4 July instead. It can be noticed that less significant government representatives were present at the central celebration in Bela Crkva as the time passed. Tito and the highest federal officials were replaced by the politicians of the local and regional level with one or a few representatives of the republican and federal level. The speeches at the Day of the Uprising commemorations always referred to the relevant and ongoing issues in the sphere of economy, internal, and foreign political affairs but always against the backdrop of the narrative of Yugoslavia continuing the emancipatory tradition of 7 July. Nationalism as the idea opposing and endangering everything 7 July stood for, emerged as a dominant discourse from the commemoration in 1971 on and remained significant throughout the 1980s. Nevertheless, regardless of the political and economic changes and the shifts in references in the commemorative discourses, the main interpretation of what happened on 7 July and its significance remained the same throughout the entire Yugoslav period.

Based on the analysis of the commemoration speeches and newspaper coverage of the Day of the Uprising during the Yugoslav period, three main themes can be traced. First, the act of killing the two gendarmes by the Partisan was interpreted in collective terms. Španac personified the people of Serbia and his act as the day when "the Serbian people took arms to defend their right to life and freedom", "when the Serbian people screamed loudly that they loved freedom above all", or "when the Serbian people took arms and fought their way to the victory." In a similar manner, the Memorial to the Uprising by Bogdan Bogdanović that was erected in 1971 in Bela Crkva includes the inscription "This is where Serbia said 'Freedom'”. While Španac personifies the Serbian people, the gendarmes symbolize the nameless servants of the occupation and, unlike Španac, they have never been mentioned at commemorations by names. The break with the Kingdom of Yugoslavia is another important point of reference, the 1941 uprising being represented as the rising of people to the popular revolution after 23 years of oppression.

Second, the 1941 uprising was narrated as representing the continuity with the uprisings and battles in the Serbian history, most notably 
with the 1804 Serbian Uprising against the Ottoman Empire and the 1389 Kosovo Battle. As summarized, in 1941, the Serbian people "strongly took the rudder of destiny in their hands once again and continued through history following the path they had strived for centuries" ${ }^{38}$ Finally, what was constantly emphasized was that the uprising that began on 7 July had been carefully planned and prepared by the Communist Party of Yugoslavia and that the uprising was an inseparable part of the Yugoslav socialist revolution.

\section{The Day when a Serb Fired at Serbs}

The reinterpretation of the Second World War has been very important for the political actors that came to power in Serbia after the fall of Slobodan Milošević in 2000. The significance of the war for the legitimacy of Yugoslav state socialism made its re-evaluation crucial for the process of rejection and delegitimization of Yugoslavia and everything associated with it. The state institutions have invested enormous efforts in inverting the previously dominant image of the war, not limited to but including the changes to street names, legal acts, state-sanctioned history textbooks, and media projects. The master commemorative narrative of the Second World War in post-2000 Serbia has been based on the view of the entire war and socialist period that followed through the narrow lens of the post-war trials and executions. This narrow view of a long and complex historical period has two outcomes. First, the focus on the revolutionary violence criminalizes the People's Liberation Movement and socialist Yugoslavia, neglecting other dimensions of this historical experience, especially the positive ones. Second, the negative image of the Partisans as perpetrators goes hand in hand with the positive reinterpretation of their opponents, whose wartime activities and collaboration are neglected by focusing strictly on their victimhood, turning them into innocent victims of communism. As Milosavljević summarizes, the revival of the collaborationist movements has the goal of switching the value positions: antifascism is rejected and reduced to communist crimes and collaborators are socially accepted as defenders of the nation. ${ }^{39}$

38 Mihailo S. Petrović, "Sedmi jul - dan ustanka u Srbiji”, Politika 12026, 7. 7. 1945.

39 Olivera Milosavljević, "Geschichtsrevisionismus und der Zweite Weltkrieg”, Mythos Partizan. (Dis)Kontinuitäten der jugoslawischen Linken: Geschichte, Erinnerunge und Perspektiven, ed. Đorđe Tomić et al., (Münster: Unrast Verlag, 2013), 227. 
The dominant interpretation of 7 July in contemporary Serbia is directly linked to the interpretation of the Second World War in Yugoslavia that places emphasis on the civil war dimension of the war, ascribing the guilt for the beginning of the civil war to the Communist Party of Yugoslavia and the People's Liberation Movement and neglecting other aspects of the nature of the war in the Yugoslav context. ${ }^{40}$ In this interpretation, 7 July becomes the day when the shots fired by Žikica Jovanović Španac started the civil war within the Serbian nation. If the revolutionary dimension of the People's Liberation War is acknowledged, it is interpreted in strictly negative terms as illegitimate strive of communists for takeover of power.

The changes to public holidays in Serbia were undertook soon after the overthrow of Slobodan Milošević. The 1997 Law on Holidays still included 7 July as the Day of the Uprising, still celebrated at the level of the Republic of Serbia. The Day of the Uprising was abolished as a public holiday by the Law on the State and Other Holidays adopted by the National Assembly on 9 July 2001. The draft of the legislation was based on the recommendation made by the Commission for State Holidays founded by the Government earlier in 2001, comprised of historians and representatives of minorities. The Fighter's Day on 4 July was removed from the official calendar together with 7 July. In return, the law introduced new public holidays such as Saint Sava's Day, Saint Vitus Day, and 15 February as

40 Such view of the war has been especially prevailing in the publications coming from the political emigration. Taking Claudio Pavone's understanding of the three wars within one that the Italian Resistance had to fight simultaneously in the Second World War, the war that the People's Liberation Movement fought in the Yugoslav context can also be classified as tridimensional: the patriotic war against the occupation, the civil war against the domestic collaborators, and the class war against the previous socioeconomic order of the Kingdom of Yugoslavia. On the other hand, discussing the conflict between the Partisan and the Chetnik movement in particular, Ranko Končar sees the Second World War in Yugoslavia as primarily a liberation war but with the elements of the civil war that developed as a part of the military antioccupation strategy of the Partisan movement and not as a part of its ideological physiognomy and orientation. Claudio Pavone, A Civil War. A History of the Italian Resistance, (London: Verso Books, 2014); Krunoslav Stojaković, "Revolucionarno nasilje u Narodnooslobodilačkom ratu”, Kazna i Zločin: Snage kolaboracije u Srbiji, ur. Milan Radanović (Beograd: Rosa Luxemburg Stiftung, 2015), 21; Ranko Končar, "Istorijskim mišljenjem protiv ideoloških i političkih upotreba prošlosti”, Antifašizam pred izazovima savremenosti, ur. Milivoj Bešlin, Petar Atanacković, (Novi Sad: AKO, 2012), 121-139. 
the Statehood Day. ${ }^{41}$ The Minister of Justice at the time, Vladan Batić, started the parliamentary proceeding by introducing the law proposal and explaining that the abolishment of certain holidays had been based on the idea that "there were more significant dates in the history of Serbia and the dates that were much less ideologized". ${ }^{2}$

The discussion on the Law on the State and Other Holidays in the parliament lasted nine hours. Finally, the law was adopted with the majority of votes in favour where 123 out of 183 representatives present at the proceeding voted in favour, 39 against, and 21 did not vote. Many of those who criticized the law for various reasons eventually voted in favour as well. When it comes to the abolishment of the Fighter's Day and the Day of the Uprising, only the representatives of the Socialist Party of Serbia (Socijalistička partija Srbije, SPS) and the Socialist People's Party (Socijalistička narodna stranka) opposed it. The members of these parties emphasized the significance and the positive values 7 July stood for as the beginning of the uprising, when "Serbia joined all freedom-loving democratic states of the world, beginning the fight against the fascist forces".43 While the other speakers at the proceeding repeatedly pointed out that there had been more significant dates in Serbian history and that 7 July had been an "ideologized holiday", the members of these only nominally socialist parties argued that what mattered is only that 7 July symbolized the beginning of the uprising against fascism. The discourse about the need to preserve the positive values of the antifascist struggle in the Serbian society today, as seen during the 2001 parliament proceeding, became the dominant political rhetoric of the Socialist Party of Serbia later, whose representatives usually argue that this party is the only one in Serbia striving for it.

As opposed to these claims, the majority of the speakers spoke of 7 July in Bela Crkva as the beginning of the tragedy that had lasted for 60 years, representing the shooting of the two gendarmes as a Serb killing another Serb for ideological reasons. The day was described as the day of the national shame and disgrace of the Serbian nation, the day of the Serbian defeat that "symbolized the evil". Instead of the beginning of the uprising

41 On the Serbian calendar of public holidays, see: Lea David, "Impression Management of a Contested Past. Serbia's Evolving National Calendar", Memory Studies 7/2014, 472-483.

42 Narodna skupština Republike Srbije, Stenografske beleške sa sedmog vanrednog zasedanja 09.07.2001, http://www.otvoreniparlament.rs/2001/07/09/370689/, last accessed on 10.7.2017.

43 The speech by Žarko Obradović (SPS), in: National Assembly, Stenographic Notes. 
that ended with the liberation of the country, the shots by Španac became the beginning of the "fratricidal war" and the "fratricidal tragedy that we had been suffering from for half of the century and we would suffer from forever" ${ }^{44}$ Perceiving the year 2000 and themselves as representing the new beginning for the Serbian society, the parliament speakers put emphasis on the need to make a break with the past, with communism that "brought the destruction of the best people after the war, false hope, false values, positions, and ways, the downfall and complete ruination of the state". ${ }^{45}$ While some of the speakers stressed out the continuation of trauma in the society that would take more time to overcome, the others saw the abolishment of the Day of the Uprising as finally ending the deep divisions within the Serbian nation and talked about 5 October as the end of the Second World War and civil war in Serbia.

The 7 July reappeared as the Day of the Uprising in the Second World War in the 2013 State Program for Commemorating the Anniversaries of Historic Events of the Serbian Liberation Wars, the document describing "the significant anniversaries, commemorative days, national and religious holidays, as well as important Serbian figures, together with a brief description of why specific days are commemorated and exhaustive explanations of the protocol for each of them" ${ }^{46}$ As opposed to the previous version of the Program from 2009, the 2013 version reintroduced the Day of the Uprising and the Day of the Liberation of Belgrade in 1944, both abolished after $2000 .{ }^{47}$ The commemoration of the Day of the Uprising has been prescribed as the ceremony of laying wreaths on the monument to Španac in Bela Crkva, organized by the Sector for the Protection of Veterans and the Disabled of the Ministry of Labor, Employment, Veter-

44 Narodna skupština Republike Srbije, Stenografske beleške.

45 Ibid.

46 David, "Impression Management", 477.

47 The Program is composed by the Governmental Board for Fostering Traditions of the Liberation Wars of Serbia that was established in 2001 and is formed by eight representatives of several Ministries. Besides the Program, the Board is responsible for "encouraging institutions, organizations, associations, and citizens to foster traditions of the liberation wars; following, coordinating, and directing activities in commemorating the significant historical events; giving opinion to those initiating erecting monuments and other memorials of the significant historical events; initiating, encouraging, and following the preservation and maintenance of monuments and other memorials of the significant historical events; and cooperating with the institutions responsible for taking care of monuments and memorials of the Serbian liberation wars abroad“.Vlada Republike Srbije, Odluka o osnivanju Odbora za negovanje tradicija oslobodilačkih ratova Srbije, Službeni glasnik Republike Srbije 38/97 and 46/01. 
ans, and Social Affairs in cooperation with the Ministry of Defense and the Municipality of Krupanj. ${ }^{48}$

The return of the holidays related to the People's Liberation War after their abolishment in the immediate post-2000 period is an aspect of the wider tendency entitled "the revision of the revision" by Stojanović. ${ }^{49}$ By this, she refers to the shift in the relation to the Second World War that has started happening since 2007 and is linked to the relations with the Russian Federation, not really changing the dominant interpretation of the Second World War in Serbia, but creating a version of the war "for foreign, Russian, use". ${ }^{50}$ This shift is most obvious in the sudden largescale celebrations of the Day of the Liberation of Belgrade and the Victory Day. Although not connected to the relations with Russia, the reestablishment of the Day of the Uprising fits this paradigm because it is based on the similar appropriation of Yugoslav antifascism and its transformation through ethnification and separation from its ideological and revolutionary dimension.

On the local level in Bela Crkva, there are two parallel commemorations happening every year regardless of the official status of 7 July. The Serbian Orthodox Church organizes the commemoration of Lončar and Braković a few hundred meters away from the Day of the Uprising commemoration. The commemoration of the Day of the Uprising, even after it was re-established as a holiday in 2013, has been much smaller and much less festive than during the Yugoslav period. The church commemoration revolves around the narrative of the tragedy when a Serb shot two Serbs. In 2000, the widow of Bogdan Lončar with the support of the Serbian Orthodox Church erected a monument to him in the church yard, across the street from the uprising memorial. At the unveiling ceremony, the local priest Ljubomir Ranković repeated numerous times, "May it never happen again that a Serb kills a Serb!" while hundreds of gathered people answered unanimously - "May it never happen again!"51 The monument to Milenko Braković was built two years later, both gendarmes visually represented wearing their uniforms. The memorial to Braković contains the inscriptions "You were killed by a godless brotherly hand which was the

48 Odbor za negovanje tradicija oslobodilačkih ratova Srbije, „Državni program obeležavanja godišnjica istorijskih događaja oslobodilačkih ratova Srbije“, 12.3. 2013.

49 Dubravka Stojanović, "Revisions of the Second World War History in Serbia”, Serbia and the Serbs in World War Two, eds Sabrina P. Ramet, Ola Listhaug, (Basingstoke: Palgrave Macmillan, 2011), 261.

50 Ibid., 262.

51 „Dve Srbije na sto metara”, Glas javnosti, 9. 7. 2000. 
sin and the shame of the entire Serbian nation" and "May it never happen again that a Serb kills a Serb." In July 2016, on the $75^{\text {th }}$ anniversary, the Serbian Orthodox Church added another plaque connecting the two monuments and emphasizing "Never again!"

\section{Legal Reinterpretation of 7 July}

In 2006, the National Assembly of Serbia adopted the first Rehabilitation Act, introducing legal rehabilitation for those who lost their lives, freedom, or rights, with or without a court or administrative decision, because of political and ideological reasons, after 6 April $1941 .{ }^{52} \mathrm{Bog}-$ dan Lončar and Milenko Braković were rehabilitated at the Regional Court in Šabac in 2008, with the court decision that resembled the discussion in the Serbian parliament in 2001. In the decision, the court council concluded that the gendarmes had lost their lives as victims of persecution and violence, without a trial or court decision, and without any concrete guilt, primarily with the goal of evoking fear among the others who might have opposed the Partisan movement and the ideology of the Communist Party of Yugoslavia. ${ }^{53}$ The decision interpreted the goal of the Communist Party of Yugoslavia as not primarily the liberation but the revolutionary takeover of power, which is why Lončar and Braković were killed, what formally represented the beginning of the communist revolution within and under the cover of the struggle for liberation from the fascist occupation. ${ }^{54}$ The court decision offered its interpretation of the meaning of the assassination, arguing that it could be symbolically understood as the beginning of the civil war in Serbia, because the gendarmes were not occupiers or people's enemies, but the representatives of the legitimate authorities of the Serbian state under the occupation that had been established according to the international agreement - the capitulation of Yugoslavia in April 1941. According to the court, their rehabilitation thus represents the beginning of the national reconciliation of the divided Serbian nation. ${ }^{55}$

The rehabilitation request was filed by Stana Munjić, the local journalist without any familiar connection to the gendarmes. Her reason for starting the rehabilitation process were two announcements about 7 July published earlier that year on the websites of the Ministry of Defence

\footnotetext{
52 Zakon o rehabilitaciji, Službeni glasnik Republike Srbije 33/06.

53 Okružni sud u Šapcu, Reh. br. 11/08, Rešenje, 6.

54 Ibid.

55 Ibid.
} 
and Ministry of Labour and Social Affairs respectively that were, according to Munjić, in opposition to the "first acknowledgement by the state that the event in Bela Crkva had been one of the forgeries of the official Serbian history after the Second World War" ${ }^{\prime 56}$ In the request, she explains that she "considers it her obligation to contribute to the prevention of further deviation, because the manipulation of history continues and the state does not respect its own decision about the abolishment of 7 July as the official holiday". ${ }^{57}$ Munjić had previously interviewed Lončar's widow, whose testimony had been used for a book and two local television documentaries,that Munjić submitted to the court as the evidence that "the Serbian gendarmes killed on 7 July had not been enemies of any kind, traitors of Serbian people, or collaborators, but the first victims of the civil war in Serbia". ${ }^{58}$ Interestingly, both testimony and the submitted materials were based on the widow's story, although the widow had not been present in Bela Crkva on 7 July 1941.

The plaintiffs in rehabilitation processes in Serbia are often persons without any personal relation to those to be rehabilitated, such as Stana Munjić. The 2006 Rehabilitation Act defines that a rehabilitation request can be filed by "any natural or legal person". ${ }^{59}$ In the court practice, it is usually descendants, often supported by politically motivated organizations and groups. This is especially the case with the rehabilitation of prominent persons of the Second World War period, such as Milan Nedić, whose rehabilitation process is ongoing. The implementation of the rehabilitation legislation in Serbia always starts with an initiative from below. As the legislation defines the use of the non-adversarial proceeding, those who request rehabilitation submit documentation and invite witnesses and there is no opposing side in the courtroom. ${ }^{60}$ In this sense, the state has offered the legal framework that enables memory consumers to use the courtroom as the platform for their interpretation of the past. Many of the groups that support rehabilitation processes, such as the Association of Political Prisoners and Victims of Communism, organize and take part in the commemorations and erect semi-official or unofficial memorials. Similarly to Stana Munjić, their activities are based on the perception

56 Referring to the Parliament's abolishment of the Day of the Uprising. Zahtev za rehabilitaciju, in: Okružni sud, Reh.br. 11/08.

57 Ibid.

58 Zahtev za rehabilitaciju, in: Okružni sud, Reh.br. 11/08, 2.

59 Zakon o rehabilitaciji, Act 2.

60 The 2011 Rehabilitation Act introduced the adversarial proceeding. 
that the state authorities have not done enough regarding the overcoming of the communist past and they often ascribe that issue to the presence of communists in the state institutions. Gojko Lazarev, the judge who presided over the court council in the rehabilitation process of Lončar and Braković, shares the same opinion and has been active in the local context, most notably by financially supporting building of the memorial church to the victims of communist terror in Šabac and speaking out in media.

The case of Lončar and Braković is also significant because it was the first case in which a historian appeared as an expert witness, which later became a regular practice in rehabilitation processes. The analysis of the numerous rehabilitation cases shows that positioned historians who are expected to provide the opinion in favour of someone's rehabilitation are those who testify. In case of Lončar and Braković, the court invited Kosta Nikolić from the Institute of Contemporary History to submit a written opinion, a large part of which was copied in the court decision as an argument in favour of rehabilitation. The essay argued that the primary goal of the Communist Party and the Partisans was the revolution and seizure of power rather than the liberation, which is why the Partisans attacked predominantly Serbian authorities at the beginning of the war. ${ }^{61}$ According to Nikolić and the later court decision: "After the military defeat and the occupation, in the following four years the large overturn happened in the Serbian nation, society, and the state. One whole world was destroyed with the replacement of Serbian royalists with Yugoslav communists and the irony is that Germans had a small or almost no role in it." ${ }^{62}$ Furthermore, Nikolić argued that the celebrations of 7 July in Yugoslavia had had the purpose of justification of the violent takeover of power by the Communist Party. Finally, he reproduced the dominant narrative that "celebrating the murder of Lončar and Braković had left long-term negative consequences and obstructed the process of national reconciliation and overcoming still strong ideological divisions." He ended the essay with the recommendation to rehabilitate them, arguing that it would represent a great contribution to facing the totalitarian legacy in the Serbian

61 The expert opinion by Kosta Nikolić, 15. Nikolić further explains that it was this dominant goal of the socialist revolution which hindered the existence of a unified front with the other antifascist group - the Serbian royalist movement (the Chetniks). The essay revolves around the interpretation of the Chetniks as an antifascist movement, presenting it as the widely recognized and legitimate throughout the war, as opposed to the Partisans.

Kosta Nikolić's written report; Decision, in: Reh.br. 11/08. 
society that still represented a large obstacle to the full modernization and democratization of Serbia.

\section{Concluding Remarks}

The event in Bela Crkva of 7 July 1941 has gone through numerous reinterpretations since 1945, as the day that marked the beginning of the uprising against the occupation, the day when the socialist revolution began, when the civil war started, and as the beginning of the period when the whole society was destroyed. The act of shooting the two gendarmes has never been interpreted as the act itself but more as the act that finally led to the large changes in the socio-political space. While this was ascribed positive values during state socialism, it has been deemed negatively in contemporary Serbia since 2000 . In the period immediately after the overthrow of Slobodan Milošević, the abolishment of the Day of the Uprising as a public holiday was an aspect of the process of overcoming and separation from the communist past, understood as crucial. Those who came to power in 2000 saw Milošević as the last communist ruler and themselves as the carriers of the democratic transition. The abolishment of the Yugoslav holidays represented only a segment of the official politics of memory on the Second World War and state socialism that has had the purpose of strengthening the legitimacy of the current political order through the delegitimization of the previous one.

The example of 7 July also shows the serious inconsistencies in the official memory politics and its mechanisms in contemporary Serbia. Although the date was removed from the official calendar and ceased to be a public holiday in Serbia, it was re-established as the Day of the Uprising in the Second World War in 2013. Even though without the status of a public holiday as before 2001, 7 July is nevertheless officially commemorated in Bela Crkva with the presence of the governmental and municipal representatives. As opposed to that, Lončar and Braković, who were rehabilitated in 2008 as the first victims of the civil war and victims of communist persecution and violence, legally remain rehabilitated as such. 


\section{Sources and Literature}

Sources

- Odbor za negovanje tradicija oslobodilačkih ratova Srbije. „Državni program obeležavanja godišnjica istorijskih događaja oslobodilačkih ratova Srbije“, 12. 3. 2013.

- Vlada Republike Srbije. Odluka o osnivanju Odbora za negovanje tradicija oslobodilačkih ratova Srbije. Službeni glasnik Republike Srbije 38/97 and 46/01.

- Narodna skupština Republike Srbije, Stenografske beleške sa sedmog vanrednog zasedanja 09.07.2001, http://www.otvoreniparlament. rs/2001/07/09/370689/, last accessed on 10. 7. 2017.

- $\quad$ Okružni sud u Šapcu, Reh.br. 11/08.

- $\quad$ Zakon o rehabilitaciji. Službeni glasnik Republike Srbije 33/06.

- Testimonies of Stanko Popović. 24. 8. 1959.

- $\quad$ Testimonies of Sredoje Knežević. 24. 8. 1959.

- $\quad$ Testimonies of Bogoljub Lazić. 24. 8. 1959.

Newspapers

- $\quad$ Glas javnosti

- Politika

\section{Literature}

- Apor, Péter. "Eurocommunism. Commemorating Communism in Contemporary Eastern Europe". A European Memory? Contested Histories and Politics of Remembrance, eds Malgorzata Pakier, Bo Strath, 233246. New York: Berghahn Books, 2010.

- $\quad$ Berger, Stefan and Bill Niven. Writing the History of Memory. London: Bloomsbury Academic, 2014.

- $\quad$ Berger, Stefan and Bill Niven. "Writing the History of National Memory". Writing the History of Memory, eds Stefan Berger, Bill Niven, 135157. London: Bloomsbury Academic, 2014.

- Bodnar, John. Remaking America: Public Memory, Commemoration, and Patriotism in the Twentieth Century. Princeton: Princeton University Press, 1992.

- $\quad$ Burke, Peter. Varieties in Cultural History. Ithaca: Cornell University Press, 1997.

- Connerton, Paul. How Societies Remember. New York and Cambridge: Cambridge University Press, 1989. 
- David, Lea. "Impression Management of a Contested Past. Serbia's Evolving National Calendar". Memory Studies 7/2014, 472-483.

- Höpken, Wolfgang. "Vergangenheitspolitik im sozialistischen Vielvölkerstaat. Jugoslawien 1944-1991”. Umkäpfte Vergangenheit. Geschichtsbilder, Erinnerung und Vergangenheitspolitik im internationalen Vergleich, eds Petra Bock, Edgar Wolfrum, 210-247. Göttingen: Vandenhoeck \& Ruprecht, 1999.

- Kansteiner, Wulf. "Finding Meaning in Memory: A Methodological Critique of Collective Memory Studies". History and Theory 41:2/2002, 179-197.

- Karge, Heike. "Practices and Politics of the Second World War Remembrance: (Trans-)national Perspectives from Eastern and Southeastern Europe". A European Memory? Contested Histories and Politics of Remembrance, eds Malgorzata Pakier, Bo Strath, 137-147. New York: Berghahn Books, 2010.

- $\quad$ Karge, Heike. Steinerne Erinnerung - versteinerte Erinnerung? Kriegsgedenken in Jugoslawien (1947-1970). Wiesbaden: Harrassowitz Verlag, 2010.

- Kirn, Gal. "Transnationalism in Reverse: From Yugoslav to Post-Yugoslav Memorial Sites". Transnational Memory, eds Chiara de Cesari, Ann Rigney, 313-338. Berlin: De Gruyter, 2014.

- Končar, Ranko. „Istorijskim mišljenjem protiv ideoloških i političkih upotreba prošlosti“'. Antifašizam pred izazovima savremenosti, eds Milivoj Bešlin, Petar Atanacković, 121-139. Novi Sad: AKO, 2012.

- $\quad$ Koren, Snježana. Politika povijesti u Jugoslaviji (1945-1960). Komunistička partija Jugoslavije, nastava povijesti, historiografija. Zagreb: Srednja Evropa, 2012.

- Manojlović Pintar, Olga. „(Ne)vidljiva mesta sećanja. Spomenici crvenoarmejcima u Srbiji“. Oslobođenje Beograda 1944, 545-553. Beograd: Institut za noviju istoriju, 2010.

- Mark, James. The Unfinished Revolution: Making Sense of the Communist Past in Central-Eastern Europe. London: Yale University Press, 2010.

- Milosavljević, Olivera. "Geschichtsrevisionismus und der Zweite Weltkrieg”. Mythos Partizan. (Dis)Kontinuitäten der jugoslawischen Linken: Geschichte, Erinnerunge und Perspektiven, ed. Đorđe Tomić et al., 222234. Münster: Unrast Verlag, 2013.

- $\quad$ Mitrović, Dojčilo. Zapadna Srbija 1941. Belgrade: Nolit, 1975. 
- $\quad$ Molden, Berthold. "Resistant Pasts versus Mnemonic Hegemony. On the Power Relations of Collective Memory". Memory Studies 9:3/2016, 125-142.

- $\quad$ Pavone, Claudio. A Civil War. A History of the Italian Resistance. London: Verso Books, 2014.

- $\quad$ Ramet, Sabrina and Sladjana Lazić. "The Collaborationist Regime of Milan Nedić". Serbia and the Serbs in World War Two, eds Sabrina P. Ramet, Ola Listhaug, 17-44. Basingstoke: Palgrave Macmillan, 2011.

- Schmid, Harald. "Konstruktion, Bedeutung, Macht. Zum kulturwissenschaftlichen Profil einer Analyse von Geschichtspolitik". Geschichtspolitik und sozialwissenschaftliche Theorie, eds Horst-Alfred Heinrich, Michael Kohlstruck, 75-98. Stuttgart: Steiner, 2008.

- Sindbaek, Tea. Usable Histories? Representations of Yugoslavia's Difficult Past from 1945 to 2002. Aarhus: Aarhus University Press, 2012.

- Spoja, Vjekoslav. „Bio sam kraj Žikice kad je pucao“. Ustanak naroda Srbije 1941, Vol. 2, 673-679. Beograd: Vojno delo, 1964.

- Stojaković, Krunoslav. „Revolucionarno nasilje u Narodnooslobodilačkom ratu“. Kazna i Zločin: Snage kolaboracije u Srbiji, ur. Milan Radanović, 11-28. Beograd: Rosa Luxemburg Stiftung, 2015.

- Stojanović, Dubravka. "Revisions of the Second World War History in Serbia". Serbia and the Serbs in World War Two, eds Sabrina P. Ramet, Ola Listhaug, 247-364. Basingstoke: Palgrave Macmillan, 2011.

- Stojanović, Dubravka. „U ogledalu drugih“. Novosti iz prošlosti: Znanje, neznanje, upotreba i zloupotreba istorije, prir. Vojin Dimitrijević, 1333. Beograd: Beogradski centar za ljudska prava, 2010.

- Sundhaussen, Holm. Jugoslawien und seine Nachfolgestaaten 19432011. Eine ungewöhnliche Geschichte des Gewöhnlichen. Vienna: Böhlau, 2012.

- Sundhaussen, Holm. "Jugoslawien und seine Nachfolgestaaten. Konstruktion, Dekonstruktion und Neukonstruktion von "Erinnerungen" und Mythen". Mythen der Nationen. 1945 - Arena der Erinnerungen, Bd. 1, ed. Monika Flacke, 373-427. Berlin: Deutsches Historisches Museum, 2004.

- $\quad$ Traverso, Enzo. Left-Wing Melancholia. Marxism, History, and Memory. New York: Columbia University Press, 2017.

- Wertsch, James. Voices of Collective Remembering. New York: Cambridge University Press, 2002.

- Zerubavel, Yael. Recovered Roots: Collective Memory and the Making of Israeli National Tradition. Chicago: Chicago University Press, 1995. 


\title{
Резиме
}

\author{
Јелена Ђуреиновић
}

\section{Реинтерпретација 7. јула: Од прве устаничке пушке до почетка грађанског рата}

\begin{abstract}
Апстракт: Чланак анализира историју сећања на 7. јул 1941. у контексту политике сећања на Други светски рат у Србији. Иако је заиста био малих размера, догађају у Белој Цркви 7. јула 1941. године увек је придаван велики значај и у социјалистичкој Југославији и савременој Србији. Његова интерпретација ипак се мењала и представљала је огледало хегемоних историјских наратива о Другом светском рату и њихових трансформација. Значења и вредности које су приписиване 7. јулу и његовим главним актерима су у фокусу овог рада, који користи дијахронијски приступ сећању са нагласком на постјугословенски период.
\end{abstract}

Кључне речи: политика сећања, Други светски рат, Југославија, устанак 1941. године, рехабилитација

Ова студија анализира историју сећања на Дан устанка у ширем контексту политике сећања на Други светски рат у Србији од послератног периода до данас, са посебним фокусом на постјугословенски период. Догађају у Белој Цркви 7. јула 1941. године, иако је објективно био малих размера, увек је придаван велики значај и у социјалистичкој Југославији и савременој Србији. Међутим, интерпретација убиства жандара Богдана Лончара и Миленка Браковића, које је извршио Живорад Јовановић Шпанац, мењала се и представљала је огледало хегемоних историјских наратива о Другом светском рату, као и њихових трансформација током времена. У овом раду највећа пажња посвећена је значењима и вредностима које су приписиване 7. јулу и његовим главним актерима. Кроз историјску перспективу сагледане су званичне политике сећања, главни комеморативни наративи на којима се оне заснивају и њихова политичност. Након кратког теоријског увода, рад разматра обележавање Дана устанка у југословенском периоду, његово укидање и реинтерпретацију након 2000. године и судску рехабилитацију Лончара и Браковића. 